

\title{
Ihor Lossovskyi \\ UKRAINE'S MAIN DIPLOMATIC PRIORITIES IN CONFRONTING RUSSIAN AGGRESSION
}

\begin{abstract}
The article attempts to analyze Ukraine's current efforts to counter Russian aggression at a wide range of diplomatic platforms. Based on the author's analysis of various diplomatic tracks, specific proposals are made to optimize and coordinate the necessary actions of Ukraine to ensure security and sovereignty, restore its territorial integrity within Ukraine's internationally recognized borders, in the current geopolitical conditions in the world and European region. The author proposes to focus on the complex threefold task of joint proper realization of the three components of priority political and security efforts of Ukraine: fullfleged implementation of the Budapest Memorandum, in accordance with the assurances guarantees provided to Ukraine by five nuclear states - UN SC permanent members (the USA, UK, France, Russia and China); deployment of the UN International Peacekeeping Operation in Eastern Ukraine, which will consist of three important integral components: the international military peacekeeping contingent; a transitional international civil administration that will act as a temporary international local «government»; international transitional police and justice, whose responsibilities will include the formation of a local law enforcement and judicial system in accordance with international law and the legislation of Ukraine. The third important component ("pillar") of Ukraine's afforts to ensure security, sovereignty and territorial integrity in its counteraction to Russian aggression should be the continued active involvement of OSCE mechanisms, norms, principles and institutions. The article analyzes in detail the role and contribution of this Organization in ensuring the security, sovereignty and territorial integrity of Ukraine in the face of Russian aggression.
\end{abstract}

Keywords: Russian aggression, sovereignty and territorial integrity, international guarantees, Budapest Memorandum, UN peacekeeping mission, transitional civilian administration, Helsinki process, OSCE, SMM.

Сьомий рік триває російсько-українська війна, спричинена російською агресією проти України, окупацією Автономної Республіки Крим (АРК) та частини Донбасу, спробами анексії АРК та м. Севастополя. Усі ці роки Збройні Сили України (ЗСУ) на фронті, а українська дипломатія на міжнародних дипломатичних майданчиках, завдають героїчного, високопрофесійного та успішного спротиву переважаючим за своїми ресурсами та кількісними показниками силам супротивника, що володіє другим за потужністю ядерним військовим арсеналом та є другою конвенціональною військовою потугою у світі.

Значних зусиль на цьому фронті українська дипломатія продовжує докладати насамперед на міжнародних майданчиках системи ООН у Нью-Йорку та ОБСЕ - у Відні. Також певні зусилля докладались у форматі країн - підписантів Меморандуму про гарантії безпеки у зв'язку з приєднанням України до Договору про нерозповсюдження ядерної зброї (далі - Будапештський меморандум 1994 р., БМ), зокрема заклики до скликання консультацій відповідно до прописаних у документі можливостей проведення таких консультацій у разі загрози безпеці й територіальній цілісності України. Упродовж 2014-2015 pр. тодішній Міністр закордонних справ України П. Клімкін принаймні тричі офіційно звертався до країн - підписантів БМ 3 ініціативою про проведення консультацій відповідно до зобов'язань, узятих ядерними державами в рамках цього документа. Проте через безпідставну відмову Росії брати участь у таких консультаціях вони не проводилися.

Автор цієї статті, спираючись на свій попередній досвід активної участі в інтенсивних переговорних процесах у рамках міжнародних безпекових організацій (ОБСЕ, зокрема щодо військово-політичного виміру цієї організації (ФБС, СКГ, ККВН та ін.), МАГАТЕ, Міжнародний режим експортного контролю над звичайними озброєннями «Вассенаарська домовленість» та ін.), а також ураховуючи безпосередню участь у міжнародних зусиллях з підтримання миру на Балканах, у ситуації, що склалася, у світлі триваючої російської агресії проти Укра- 
їни вважає, що фундаментальною, всеохопною відповіддю України та всієї світової демократичної спільноти має стати рішуче, комплексне, усебічне залучення трьох важливих складових частин («стовпів») забезпечення суверенітету, територіальної цілісності та безпеки України. Вони схарактеризовані нижче.

1. Механізми імплементації положень БМ, відповідно до якого п'ять ядерних держав постійних членів Ради Безпеки ООН (США, Велика Британія, Франція, Росія та Китай) гарантували Україні безпеку, суверенітет і територіальну цілісність у разі відмови останньої від третього у світі за своєю потужністю ядерного арсеналу. У 2014-2015 рр. автором публікації на основі аналізу фундаментальних основоположних документів міжнародного права, російського та українського національних законодавств було проведено дослідження питань правового статусу цього найважливішого для гарантування безпеки й територіальної цілісності України та світової системи нерозповсюдження міжнародно-правового безпекового документа. Здійснена робота уможливила зробити беззаперечний висновок про те, що БМ є повноцінним міжнародно-правовим багатостороннім договором, обов’язковим для виконання всіма його сторонами, насамперед Росією - головним, принциповим, зухвалим порушником положень цього документа та всього міжнародного права, а також іншими країнами-підписантами (окрім України, що виконала свої зобов'язання у повному обсязі), які ухилилися від своїх принципових зобов'язань за документом, не надали нашій державі належної допомоги для відстоювання їі суверенітету й територіальної цілісності в протистоянні наодинці агресії Росії - ядерної держави, другої військової потуги у світі.

Результати досліджень представлені низкою наукових публікацій, зокрема [1-3]. Незважаючи на певну втрату можливостей щодо безпосереднього застосування цього документа відразу після початку російської агресії проти нашої держави, цей меморандум і сьогодні не втрачає свого значення як юридично зобов'язуючий договір міжнародного права. Він може бути затребуваний і має залишатися на порядку денному переговорного процесу з відновлення суверенітету й територіальної цілісності України.

2. Миротворчі можливості ООН та її досвід проведення успішних міжнародних масштабних комплексних операцій з підтримання миру із залученням трьох важливих невід'ємних компонентів: 1) міжнародного військового контингенту, який гарантує дотримання перемир'я та повне розведення сторін, а в разі неготовності сторін - примушує їх до миру; 2) перехідної міжнародної цивільної адміністрації, яка тимчасово виконує широкі функції місцевого «уряду» до моменту передачі влади демократично обраним місцевим національним адміністративним структурам відповідно до законодавства країни перебування; 3) міжнародної перехідної поліції та юстиції, що складаються з кваліфікованих міжнародних фахівців та експертів, обов'язки яких полягають у формуванні місцевої правоохоронної та судової систем згідно із міжнародним правом та законодавством приймаючої країни. Дослідження автора цієї статті стосовно міжнародного досвіду розгортання та функціонування таких комплексних операцій з підтримання миру в 1995-1998 рр. на Балканах також представлені низкою попередніх наукових публікацій, також і [4-6].

3. Важливою складовою частиною («стовпом») забезпечення безпеки, суверенітету й територіальної цілісності України у її протидії російській агресії є продовження активного залучення Гельсінського процесу та механізмів найбілышої і найбілыш розгалуженої у світі регіональної безпекової організації - ОБСЕ, її принципів, основоположних правових і нормативних документів та автономних інститутів. 3 огляду на попереднє висвітлення у згаданих публікаціях питань, пов'язаних з першими двома складовими частинами, подальший текст цієї статті переважно присвячений питанням ролі та внеску Гельсінського процесу та ОБСЕ у забезпеченні безпеки, суверенітету і територіальної цілісності України в протистоянні російській агресіï.

Як відомо, 1 серпня 1975 р. європейськими державами, до яких приєдналися США та Канада, було ухвалено Заключний акт Наради з безпеки та співробітництва у Европі (Гельсінську декларацію). Держави - учасниці Наради (спочатку всього 35) заявили про свої зобов'язання поважати та застосовувати у відносинах між собою та безпосередньо в межах країн 10 фундаментальних принципів (Гельсінський декалог).

I. Суверенна рівність, повага прав, властивих суверенітету, зокрема право кожної держави на територіальну цілісність і політичну незалежність. Кордони держав можуть змінюватися 
лише відповідно до міжнародного права, мирним шляхом і за домовленістю. Кожна держава має право належати до тих чи інших міжнародних організацій, бути учасником двосторонніх або багатосторонніх союзних договорів, або мати право на нейтралітет.

II. Незастосування сили або загрози силою проти територіальної цілісності, політичної незалежності.

\section{III. Непорушність кордонів.}

IV. Держави поважають територіальну иілісність кожної, утримуються від будь-яких дій проти територіальної цілісності, політичної незалежності або єдності держав, перетворення території інших держав на об'єкт військової окупації. Ніяка окупація або придбання такого роду не визнається законною.

V. Мирне врегулювання суперечок. Держави погодилися вирішувати спори лише мирними засобами, вдаючись до: переговорів, посередництва, примирення, арбітражу, судового розгляду.

VI. Невтручання у внутрішні справи. Держави зобов'язались утримуватися від втручання у внутрішні або зовнішні справи, збройного втручання або загрози такого втручання.

\section{VII. Повага до прав людини і основних свобод.}

VIII. Рівноправність і право народів розпоряджкатися своєю долею. Усі народи мають право визначати свій внутрішній і зовнішній політичний статус без втручання ззовні та самостійно здійснювати свій політичний, економічний, соціальний і культурний розвиток.

IX. Держави домовилися розвивати співробітництво як рівні між собою суб'єкти.

Х. Держави домовилися сумлінно виконувати свої зобов'язання за міжнародним правом. Якщо зобов'язання держав суперечать зобов'язанням за якимось договором, переважну силу матимуть зобов'язання за Статутом ООН [6-8].

\section{Основні завдання участі України в ОБСє до початку російської агресії 2014 р.}

Менше ніж через пів року після набуття своєї Незалежності 24 серпня 1991 р. Україна як не- залежна держава вступила до тоді ще Наради з Безпеки та співробітництва у Европі (НБСЕ), підписавши Гельсінський Заключний акт у лютому 1992 p.

Швидкий розвал Східного блоку соціалістичних країн та припинення блокового політичного протистояння в широкому Європейському регіоні на початку 1990-х років суттєво змінили Гельсінський процес, значно пом'якшуючи конфронтаційні його елементи. Це зумовило створення в 1994 р. та оформлення під час Сaміту НБСЕ у Будапешті, що відбувся на початку грудня того ж року, повноцінної, найбільшої за кількістю країн та їх сумарним населенням, регіональної міжнародної організації у світі - Opганізації з безпеки та співробітництва у Европі (ОБСЕ).

Перші дві декади свого членства в НБСЕ/ОБСЕ Україна переважно концентрувалася на питаннях використання потенціалу Організації та іiі автономних інституцій (Бюро демократичних інститутів та прав людини (БДІПЛ), Верховний комісар у справах національних меншин (ВКНМ), Представник з питань свободи 3МІ (ПС3), Секретаріат ОБСЕ 3 його Центром із запобігання конфліктам (ЦЗК)), а також інших експертних та ресурсних можливостей Організації для забезпечення розвитку процесів демократизації країни, формування та належного функціонування iㅜ національних і регіональних демократичних інститутів.

Разом із тим у сфері питань «жорсткої» безпеки та військово-політичного виміру ОБСЕ Україна ще з початків 1990-х років вимушена була теж скористатися можливостями, експертним і фінансово-ресурсним потенціалом Організації. Це було пов’язано з тим, що з перших років Української Незалежності РФ намагалася використовувати проти української державності всі наявні в неї фінансові, економічні, інформаційно-пропагандистські та військово-політичні можливості, вдаючись до залучення своєї розгалуженої агентурної мережі, використання диверсійних методів, спецслужб, внутрішніх агентів впливу та численних «корисних ідіотів» в Україні. Росія не припиняла своєї активної деструктивної діяльності 3 метою дестабілізації та протидії процесам державотворення, формування національного демократичного суспільства в нашій державі. Така їі деструктивна діяльність як на державному рівні, так і з використанням окремих 
регіональних органів, зокрема Мерії Москви та інших федеральних одиниць, відбувалася впродовж усіх років Української Незалежності та перманентно наростала. Насамперед така деструктивна та агресивна пропагандистська діяльність відбувалась у Криму та східних регіонах України.

У ті роки ОБСЕ надавала суттєву допомогу Україні в протидії імперським деструктивним намаганням РФ. Так, на відповідне запрошення Уряду України було створено Місію ОБСЕ в Україні, яка почала свою діяльність 24 листопада 1994 р. Завданнями Місії були, зокрема, підтримка роботи експертів з конституційних та економічних питань в Україні, моніторинг та звітування про ситуацію в Криму, пов'язану 3 деструктивною діяльністю Росії з підтримки та фінансування сепаратистських рухів на півострові, зокрема в контексті перебування Чорноморського флоту РФ на території України та частих провокативних дій окремих російських посадовців, серед яких мер Москви Ю. Лужков, а також російської «п'ятої колони» на півострові. У період 1993-1995 рр. навіть існувала посада «Президент Республіки Крим», яку обіймав ставленик Москви Ю. Мєшков.

Присутність Місії ОБСЕ в Україні в ті роки зіграла свою позитивну роль у справі зміцнення української державності на півострові. Гостра фаза протистояння центральної та місцевої влади в Криму була завершена в 1995 р. Новий статус Криму як автономії у складі України юридично закріпили Конституція України (1996 р.) та Конституція Автономної Республіки Крим (1998 р.). 3 цього часу Україна активно наполягала на необхідності згортання Місії [9; 10]. Термін іiі повноважень спливав 30 квітня 1999 р., i згідно з рішенням Постійної ради (ПР) ОБСЕ від 1 червня 1999 р. Місію ОБСЕ в Україні було закрито. При цьому того ж дня було започатковано Офіс Координатора проєктів ОБСЕ в Україні (КПОУ). Визначалося, що така нова форма співпраці між Україною та ОБСЕ буде грунтуватися на ініціюванні, плануванні, узгодженні, реалізації та контролі за проєктами взаємодії між відповідними органами влади України та ОБСЕ і їі інститутами. Проєкти мали стосуватися всіх аспектів діяльності ОБСЕ, брати участь у них могли як урядові, так і неурядові структури в Україні. 3 метою виконання цих завдань було створено посаду Координатора проєктів ОБСЕ в Україні, яка успішно функціонує до цього часу. Координатор, а також міжнародні та місцеві співробітники його Апарату базуються в Києві, як і співробітники попередньої Місії ОБСЕ в Україні. Координатор представляє регулярні звіти ПР ОБСЕ про хід та підсумки своєї роботи.

Організаційні умови цієї форми співпраці були додатково уточнені в окремому Меморандумі про взаєморозуміння, підписаному Урядом України та ОБСЕ. На початковому етапі особливий наголос робився на плануванні та підготовці великомасштабного проєкту «Всеохоплюючий огляд законодавства з прав людини», робота над яким розпочалася восени 1999 р. Бюджетні витрати, пов'язані з діяльністю Координатора, покриваються за рахунок щорічних бюджетів ОБСЕ, а також за рахунок добровільних внесків. За понад 20 років своєї діяльності Офіс Координатора на запит Уряду України успішно імплементував десятки важливих для України проєктів. Останніми роками програмна діяльність Координатора проєктів зосереджувалася на таких пріоритетних напрямах: сприяння проведенню Урядом України системних реформ, підтримання національного інклюзивного діалогу, зусиль української влади в подоланні наслідків збройного російсько-українського конфлікту на Донбасі, забезпечення хімічної безпеки, оцінювання екологічних наслідків та загроз військової агресії Росії на Донбасі, протидії торгівлі людьми та відмиванню грошей [11].

\section{Роль ОБСЕ в протистоянні України російській агресії}

Чи не найбільш оперативною та дієвою реакцією світової спільноти на початок російської агресії проти України стало започаткування спеціальної польової присутності ОБСЕ в Україні. Значну роль у цьому зіграла активна робота Делегації України при ОБСЕ, Швейцарське головування в цій організації у 2014 р., діяльність Генерального секретаря ОБСЕ Л. Заньєра, а також суттєва підтримка головних партнерів України - делегацій США, СС, Канади, Туреччини, Швейцарії та ін. Відповідно до рішень головного робочого органу Організації, уповноваженого приймати важливі поточні рішення, Постійної ради ОБСЕ, від 21 березня 2014p. було створено Спеціальну моніторингову місію ОБСЕ в Україні (CMM) з метою забезпечення зменшення напруженості та сприяння встановленню миру, стабільності та безпеки; спостере- 
ження та підтримки імплементації принципів і зобов'язань ОБСЕ.

Перед СММ було поставлено низку завдань (за умови функціонування на основі принципів неупередженості та прозорості): збирати інформацію та доповідати про безпекову ситуацію в зоні свого функціонування; установлювати та повідомляти факти про конкретні інциденти, у т. ч. щодо випадків порушення основних принципів та зобов'язань ОБСЕ; здійснювати моніторинг і підтримку прав людини та основних свобод, також і прав осіб, які належать до національних меншин; встановлювати задля успішного виконання своїх завдань контакти з владою на національному, місцевому, регіональному рівнях, громадянським суспільством, етнічними та релігійними групами, місцевим населенням; сприяти діалогу на місцях 3 метою зменшення напруги та сприяння нормалізація ситуації; повідомляти про будь-які обмеження свободи пересування СММ та інші перешкоди виконанню свого мандата; координувати та підтримувати роботу виконавчих структур ОБСЕ, у т. ч. ВКНМ, БДІПЛ, ПСЗ, з повною повагою до їхніх мандатів, а також співпрацювати з ООН, Радою Європи та іншими міжнародними інституціями. Через кілька тижнів, а саме 14 квітня 2014р., було підписано Меморандум про взаєморозуміння між Урядом України та ОБСЕ про встановлення цієї нової форми співпраці, а 3 червня того ж року Президент України підписав Закон про ратифікацію цього Меморандуму.

На прохання Президента України, Швейцарське головування в ОБСЕ 7 травня 2014p. призначило швейцарського посла X. Тальявіні представляти Головування ОБСЕ в Тристоронній контактній групі (ТКГ), до якої також входили представники України (колишній президент Л. Кучма) та РФ (посол М. Зурабов). Відтоді зустрічі Тристоронньої контактної групи (Україна - Росія - ОБСЕ) відбуваються регулярно. Згодом, 5 вересня 2014 р. ТКГ підписала в Мінську протокол про припинення вогню та про запуск програми політичного процесу розв'язання конфлікту, що стало першою подібною домовленістю про припинення вогню на сході України. Станом на серпень 2020 р. діяла вже 23-тя подібна домовленість. Причому, як щодо останньої домовленості, так і стосовно всіх попередніх, не можна було повною мірою говорити про тотальне припинення вогню, а лише про суттєве зменшення його інтенсивності упродовж певного часу. Це також було яви- щем позитивним, оскільки суттєво зменшувало вірогідність людських втрат з обох боків. Відповідно до згаданих домовленостей СММ узяла на себе завдання у сфері моніторингу припинення вогню.

Головний офіс СММ розташований у Києві, icнують ще регіональні офіси Місії - у Дніпрі, Донецьку, Івано-Франківську, Львові, Луганську, Одесі, Харкові, Херсоні та Чернівцях. Максимальна кількість спостерігачів, передбачених мандатом Мiciï, - 1000 осіб. Станом на серпень 2020 р. загалом працював 721 спостерігач (серед яких 133 жінки), більшість (550) спостерігачів перебувають на сході України, в зоні збройного протистояння на Донбасі. Починаючи з 2015 р., мандат СММ продовжується в березні місяці кожного року, на один рік до кінця березня наступного року. За національною представленістю в СММ працюють представники 44 держав - учасниць ОБСЕ. Серед них у якості «міжнародних спостерігачів» (international observers) працюють представники таких країн: США (54 спостерігачі), Боснія і Герцеговина (51), Болгарія (46), Велика Британія (45), Молдова (42), Російська Федерація (41), Німеччина (32), Канада (27) та ін. 3 огляду на те, що РФ є прямим учасником конфлікту, що розпочався завдяки прямій російській агресії проти нашої держави, цілком логічним було б унеможливлення участі представників РФ у складі спостерігачів СММ. Проте, враховуючи консенсусний характер ухвалення рішень в ОБСЕ, така ситуація не $є$ можливою. У разі наполягання України на виключенні спостерігачів РФ зі складу СММ Росія заблокувала би саме створення такої Місії. У результаті, на сьогоднішній день 41 спостерігач від Росії працює в СММ, що безсумнівно вносить недовіру та певний деструктивний елемент у об'єктивне висвітлення подій в зоні конфлікту. На жаль, такими є обмеження, що накладаються міжнародними організаціями, керівним принципом функціонування яких є консенсус. Одночасно в СММ працюють іще 124 «міжнародні представники» (other international staff): глава Місії, його заступники, радники, аналітики та ін., а також в якості «національних представників» (national staff) - технічні співробітники, помічники, радники, адміністративний персонал та ін., усього 441 громадянин України. 31 червня 2019 р. Главою СММ (Головним спостерігачем) є посол Туреччини Ясар Халат Чевік.

Загальний річний бюджет Місії до кінця iï поточного мандата (31 березня 2021 р.) становить 
100844500 євро, з яких 84709400 євро надходять із бюджету національних внесків держав учасниць ОБСЕ, а 161335100 євро - 3 добровільних внесків. Це при тому, що річний бюджет усієї ОБСЕ разом із автономними інститутами та польовими присутностями становить близька 138 млн євро.

На сьогоднішній день СММ є найбільшою польовою присутністю ОБСЕ, як за кількістю співробітників, так і за щорічним бюджетом, який фактично становить $73 \%$ від усього іншого бюджету Організації (42\% від усього сумарного бюджету ОБСЕ). У своїй роботі Місія використовує значну кількість сучасних технічних засобів моніторингу, серед яких - безпілотні літальні апарати (БПЛА) короткого, середнього та дальнього радіусу дії, відеокамери, у т. ч. нічного бачення, броньовані автомобілі посиленої прохідності тощо. За результатами моніторингової діяльності Місії складаються детальні регулярні щоденні, щотижневі, спеціальні, тематичні, щорічні та інші звіти, у підготовці яких беруть участь як польові спостерігачі, так і фахові спеціалісти дотичних галузей, а також аналітики. Регулярно і періодично звіти керівників СММ заслуховуються Постійною радою ОБСЕ у Відні.

Загалом, незважаючи на повторювану критику на адресу Місії, що лунає в українських 3МI, соціальних мережах та з боку окремих політиків, СММ робить значний внесок у справу незалежного, об'єктивного моніторингу військово-політичної, економічної та гуманітарної ситуації в зоні проведення військових дій на Донбасі, а також доведення зазначеної інформації як до країн - учасниць ОБСЕ, які приймають колективні рішення щодо продовження іiі роботи, так і до світових 3МІ та громадянського суспільства. СММ - єдиний і досить потужний механізм постійної/щоденної спостережної міжнародної присутності в збройному російсько-українському конфлікті, який розпочався 20 лютого 2014 p. російською агресією проти України в Криму, протизаконною окупацією і спробами анексії Автономної Республіки Крим та м. Севастополя. За умовами мандата СММ уповноважена працювати на всій території України у межах іiі міжнародно визнаних кордонів, тобто і в АРК, і в м. Севастополі, проте Російська Федерація не дозволяє СММ, як і іншим гуманітарним місіям міжнародних організацій, перебувати на півострові, висуваючи для цього абсолютно неприйнятні політичні умови.
СММ є суто спостережною (не миротворчою) місією, яка уповноважена: повідомляти про факти, які вона спостерігає та встановлює; збирати інформацію та звітувати про безпекову ситуацію, про гуманітарну ситуацію та потреби місцевого населення, сприяти доставці гуманітарної допомоги інших організацій; допомагати налагодити діалог та припинення вогню на місцях. Важливо також розуміти: СММ не уповноважена примушувати сторони до миру, вони самі повинні припинити стріляти. Місія не проводить розслідувань, а лише повідомляє про виявлені факти; не доставляє, а лише сприяє доставці гуманітарної допомоги [12].

\section{Місія спостерігачів на російських пунктах пропуску через російсько-український кордон «Гуково» та «Донецьк»}

Згідно із Берлінською декларацією від 2 липня 2014 р. міністрів закордонних справ Німеччини, Франції, Росії та України 57 держав - учасниць ОБСЕ 24 липня 2014 р. вирішили розмістити Місію спостереження на двох російських пунктах пропуску - «Гуково» та «Донецьк» на російсько-українському кордоні. Ця Місія є значно менш численною та ефективною формою міжнародної польової присутності в зоні воєнного конфлікту на Донбасі, якщо порівняти іiї із СММ. Створена вона у відповідь на формальне запрошення з боку РФ.

Місія розпочала свою роботу 30 липня 2014 p. До іï складу входять 22 міжнародні спостерігачі, включно й Глава Місії (Головний спостерігач), які працюють позмінно в групах протягом 24 год сім днів на тиждень, та декілька адміністративних і технічних працівників. Спостерігачі базуються в м. Кам'янськ-Шахтинському Ростовської області РФ. Мандат Місії продовжується кожні 4 місяці відповідним рішенням ПР ОБСЄ. Вона працює незалежно від СММ ОБСЕ, неупереджено та прозоро, контролюючи та звітуючи про ситуацію та переміщення через кордон у двох зазначених пунктах пропуску. Місія спостереження регулярно звітує перед ОБСЄ, держави-учасниці отримують щотижневі звіти. Водночас умови роботи спостерігачів Місії є дуже обмеженими. Вони не можуть безпосередньо проводити перевірку автомобілів 3 вантажем, що перетинають кордон, а лише спостерігають за ними з відстані близько 100 м, навіть не можуть користуватися біноклями або іншими технічними засобами. 
Поряд із двома згаданими пунктами пропуску через кордон проходять залізничні колії, проте від місця розташування спостерігачів їх відділяють лісопосадки, тому спостерігачі можуть фіксувати проходження потягів лише на слух. Крім того, Місія спостереження не має нормального юридичного статусу на території РФ, що вносить значні складнощі та обмеження у iii нормальне функціонування та перебування в Росії. Такі складні та обмежені умови перебування і спостереження роблять їх неефективними й такими, що мають дуже незначну додану вартість у контексті можливого реального контролю пересування особового складу та військових вантажів через неконтрольовані Україною і міжнародною спільнотою ділянки російсько-українського кордону.

3 огляду на те, що в умовах російсько-української війни на Донбасі поза контролем Уряду України перебувають близько 409 км державного кордону, делегація України на Віденських переговорах ОБСЕ, а також делегації партнерів нашої держави, серед яких США, ЕС, Канада, Велика Британія, Грузія, Молдова, Норвегія, Албанія, Ісландія, Боснія і Герцеговина, Північна Македонія, Чорногорія та інші держави, тричі на рік, під час продовження мандата Miciï на наступні 4 місяці, вимагають від РФ розширити цей мандат на інші пункти пропуску на неконтрольованій ділянці російсько-українського кордону. Такі вимоги до Росії лунають насамперед тому, що через неконтрольований Україною сегмент кордону відбуваються регулярні постачання Росією своїм незаконним підрозділам на Донбасі озброєння, військової техніки, спорядження та живої сили. Це регулярно підтверджується як звітами СММ ОБСЕ, зокрема відео- і фотофіксацією з БПЛА СММ, так і інформацією Міністерства оборони та Служби безпеки України (що постійно заперечується російською стороною - «их там нет»). У відповідь делегація Росії лише повторює мантру про те, що навіть наявний дуже обмежений мандат Спостережної Місії є результатом виявлення Росією «доброї волі» $\mathrm{i}$ «готовності співпрацювати», тому РФ не збирається в подальшому розширювати цей мандат.

Серед інших міжнародних структур, які продовжують робити певний внесок у справу протидії російській агресії та забезпечення безпеки і територіальної цілісності України, можна було би також відзначити автономні інституції ОБСЕ, серед яких розташоване у Варшаві (Польща)
БДІПЛ з його щорічним двотижневим представницьким форумом з питань імплементації зобов'язань у рамках ОБСЕ з прав людини «Human Dimension Implementation Meeting», а також ВКНМ із штаб-квартирою в Гаазі (Нідерланди).

\section{Переговорний процес у рамках ТКГ в Мінську, Нормандського формату, а також перспективи інших переговорних форматів}

Переговори в ТКГ головним чином полягають в імплементації Мінських домовленостей, які продовжують демонструвати свою незначну ефективність. Термін дії цих домовленостей формально завершився ще наприкінці 2015 р. і з того часу вже кілька разів продовжувався на один рік. Разом із тим вихідні позиції Мінських домовленостей є такими, що вже давно не відповідають реальній ситуації на фронті, оскільки фактична лінія фронту/розмежування між сторонами конфлікту з часу ухвалення «Мінських домовленостей-1» (Мінський меморандум) 19 вересня 2014 р. суттєво змінилася, російська сторона, порушуючи ці домовленості, захопила ще близько 3 тис. км² української території. Проте Мінські домовленості, незважаючи на те, що були укладені Україною в несприятливих, «стресових» для неї зовнішніх умовах, усе ще несуть у собі певний потенціал. Вони іще певний час матимуть право на паралельне існування 3 іншими переговорними форматами (про які йдеться нижче). Крім того, досить поширеними в міжнародному експертному середовищі та політикумі є помилкові (на думку автора цієї статті) уявлення, що саме до Мінських домовленостей «прив’язані» основні західні антиросійські санкції.

Упродовж шести років функціонування Нормандського (Німеччина, Франція, Україна, РФ) і Мінського (Україна, РФ, ОБСЕ) переговорних форматів очевидним є той факт, що ініціатива проведення переговорів, внесення пропозицій на обговорення під час їх тривання, формування документів, які готувалися для переговорів та за підсумками їх проведення, переважно належала російській стороні. Така ситуація пояснювалася різними причинами, зокрема переважаючими людськими, експертними та матеріальними ресурсами, які було залучено російською стороною для забезпечення проведення цих переговорів, а також сталими імперськими традиціями діяльності РФ на зовнішньополітичній арені. 
Проте в червні 2020 р., принаймні вперше за останні роки, українська делегація в Мінську перехопила ініціативу ведення переговорів у Мінському форматі. Ця ініціатива, зокрема, полягала в реформуванні української участі у Тристоронній контактній групі (ТКГ) в Мінську, підвищення рівня українських переговірників за рахунок уведення до складу делегації України депутатів Верховної Ради та окремих заступників міністрів. Крім того, до складу делегації України в якості представників Донбасу, несподівано для російської сторони, було введено декількох внутрішньо переміщених осіб (ВПО), що після тимчасової окупації частини Донбасу проживають у Києві. Такий досить ефектний та несподіваний хід української сторони фактично позбавив підгрунтя російську сторону. Це вплинуло на традиційну напористість РФ та самовпевненість у своїх силах і діях та призвело до очевидної роздратованості.

Продовжуючи приділяти увагу переговорним процесам у рамках Мінського та Нормандського форматів, українській стороні не слід було би переоцінювати ефективність та результативність цих переговорів, ураховуючи неготовність російської сторони виконувати ці домовленості сумлінно та в повному обсязі, а також суперечливий, з погляду міжнародного права, статус Мінських домовленостей та політичні умови, за яких вони були укладені.

По-перше, РФ та Україна як сторони, що брали участь у підписанні цих домовленостей, продовжують по-різному інтерпретувати їх основні положення та порядок виконання. По-друге, російська сторона взагалі відмовляється визнавати себе стороною Мінських домовленостей, як і стороною самого конфлікту, але визнає себе лише посередником, поряд із ОБСЕ. По-третє, Москва також вважає, що Мінські домовленості отримали юридично зобов'язальний характер після ухвалення відповідної Резолюції РБ ООН, яка затвердила відповідний Мінський комплекс заходів, ухвалених сторонами в лютому 2015 р. в Мінську. Разом із тим РФ, постійно наполягаючи на обов'язковості виконання Україною всіх без винятку положень Мінських домовленостей, ухиляється від обов'язковості для себе їх виконання, хоча і є стороною цих домовленостей. За цією ж логікою, РФ утримується від визнання за Мінськими домовленостями правового статусу міжнародного договору відповідно до Віденської конвенції про право міжнародних договорів (набула чинності в 1980 р.), оскільки настійливо заперечує свій статус сторони домовленостей, тоді як сторонами договорів можуть бути лише суб'єкти міжнародного права (держави або міжнародні організаціi). Уся ця російська правова еквілібристика має на меті лише одне: довести, що Мінські домовленості є юридично зобов'язальними лише для України, але не для РФ.

Зазначимо, що «Мінські домовленості-2» (Декларація лідерів Нормандської четвірки), підписані 12 лютого 2015 р., хоча й були схвалені Радою Безпеки ООН 17 лютого того ж року, проте, як свідчить правовий аналіз, в окремих пунктах не відповідають Конституції та законодавству України, положенням міжнародного права, а також нормам ОБСЕ.

\section{Інші перспективні формати переговорного процесу}

Україні необхідно продовжити роботу з метою розширення переговорних форматів, насамперед залучаючи до них Будапештських гарантів безпеки й територіальної цілісності України США, Велику Британію, а, можливо, й КНР, та відродження Женевського переговорного майданчика (США - СС - Україна - РФ), що надало би змогу залучити до переговорів найпотужніших у світі гравців (ядерні держави постійні члени РБ ООН), які 25 років тому надавали Україні письмові міжнародно-правові гарантії її безпеки та територіальної цілісності відповідно до Будапештського меморандуму 1994 р. (ці гарантії не були дотримані перед лицем російської агресії проти України) [1-3].

Меморандум є чинним, повноцінним міжнародним договором, обов'язковим для виконання його сторонами-підписантами («гарантами» незалежності та непорушності кордонів України). Насамперед це стосується Російської Федерації - головного порушника Будапештських «гарантій». Меморандум у шестисторонньому форматі на вищому рівні (США, Велика Британія, РФ, Франція, КНР, Україна) підтверджував Україні гарантії, прописані в Гельсінському Заключному акті ОБСЕ 1975 р.: поважати незалежність, суверенітет та існуючі кордони України; утримуватися від загрози силою або ії̈ застосування проти територіальної цілісності та політичної незалежності України; що ніякі озброєння ніколи не будуть використані проти неї, окрім випадків самооборони...; утримуватися від економічного примусу тощо. 
Провал Будапештських «гарантій» є сигналом світові про те, шо чи не єдиним надійним шляхом забезпечення безпеки держав $є$ розвиток власної ядерної зброї. Не один десяток «порогових» країн і таких, що мали наміри й технологічні можливості створення такої зброї, мають замислились над цією дилемою, задаючи собі майже Шекспірове питання: «Мати чи не мати?» І ситуація довкола України стає для них наочним прикладом примарності надій на «гарантії» ядерних держав - постійних членів РБ ООН. Логіка керівництва цих країн може полягати в такому: якщо «гарантії» ядерних держав не працюють для України - європейської демократичної країни, добропорядного члена світової спільноти, то вони навряд чи працюватимуть для країн, які в західній риториці називають країнами «вісі зла», «ізгоями» та країнами-«паріями» [1-3].

Проте ерозія міжнародно-правового режиму нерозповсюдження є лише одним з елементів «скриньки Пандори», яку зламав режим Путіна. Під загрозою опинилася вся міжнародна архітектура європейської та світової безпеки, сформована за підсумками Другої світової війни. Окупація та спроби анексії Росією АРК і м. Cевастополя засвідчують перший у післявоєнній історії випадок, коли одна країна незаконно у військовий спосіб захопила в центрі Європи територію іншої країни. Останнього разу в європейській історії подібні злочини здійснили нацисти А. Гітлера. У разі, якщо Росія так і залишиться непокараною за здійснення прецедента військової агресії та окупації чужих територій у XXI ст., важко уявити собі більш загрозливі подальші наслідки цього для всієї європейської безпеки. Адже на Європейському континенті $є$ чимало інших прикладів історичного існування гострих прикордонних проблем, що може спричинити значну кількість нових кривавих конфліктів у Европі.

\section{Обговорення в рамках робочих органів ОБСє питань російської агресії проти України та незаконної окупації і мілітаризації Криму, Чорного та Азовського морів}

Упродовж майже семи років російсько-української війни та агресії Росії проти нашої держави, яка розпочалася 20 лютого 2014 р., головний пункт у порядку денному ОБСЕ (насамперед, засідань Постійної ради та Форуму безпекової співпраці (ФБС)) посідали питання незаконної окупації та спроби анексії Росією АРК i м. Севастополя та триваючої агресії на Донбасі. Кардинальні зміни безпекової ситуації в регіоні Східної Європи поставили перед ОБСЕ складні завдання посилення ефективності використання всіх наявних інструментів і механізмів, здатних зупинити агресію Росії й відновити атмосферу безпеки і довіри у Європі та світі.

Хід дискусій в ОБСЄ засвідчує, що переважна більшість держав-учасниць залишається на позиціях послідовної підтримки суверенітету та територіальної цілісності України в межах іiі міжнародно визнаних кордонів. Держави виступають із засудженням протиправних дій РФ, які порушують основоположні норми міжнародного права, ключові принципи та зобов'язання в рамках ОБСЕ. Ці дії РФ створили найбільшу безпекову загрозу в регіоні за всі роки існування цієї Організації. Навіть найближчі партнери Росії та ії сателіти із СНД, ОДКБ та ЄвразЕС жодного разу не наважилися відкрито підтримати іiі у протистоянні з Україною.

У контексті забезпечення шляхів урегулювання російсько-українського конфлікту Організація продемонструвала достатню активність, запропонувавши наявні інструменти реагування на ситуацію, що склалася в результаті російської агресії: від політичного діалогу в ході регулярних і спеціальних засідань до практичної польової роботи, яку виконує ОБСЕ, та їі польової присутності в Україні. Зокрема, це стосується здійснюваних СММ моніторингу та верифікації в рамках імплементації Мінських домовленостей та завдань, які Місія спостереження ОБСЕ виконує на російських пунктах пропуску «Донецьк» $\mathrm{i}$ «Гуково», сприяння діяльності ТКГ та іiі робочих підгруп, а також активного залучення автономних інститутів ОБСЕ.

За підсумками дискусій у рамках ОБСЕ упродовж останніх років слід констатувати наявність консенсусу держав-учасниць щодо збереження за СММ ОБСС ключової ролі у сприянні врегулюванню конфлікту на Донбасі, зміцнення іiї людських і технічних спроможностей, збереження уявлення про безальтернативність мирного врегулювання конфлікту на Донбасі. При цьому перевага надається саме Мінським домовленостям, хоча ефективність останніх продовжує викликати сумнів. У контексті більш активного залучення інститутів ОБСЄ до врегулювання на Донбасі просувається участь БДІПЛ у забезпеченні спостереження за проведенням 
місцевих виборів в окремих районах Донецької і Луганської областей за існуючих норм та правил, заохочуються інші інститути, насамперед ВКНМ, щодо забезпечення моніторингу ситуації в Криму, інформування міжнародної спільноти про триваючі порушення з боку РФ прав людини, зокрема прав кримськотатарського та українського етнічного населення.

Разом із тим уже сьомий рік за військових дій на Донбасі та незаконної діяльності російської окупаційної адміністрації в Криму, що тривають, ОБСЄ продовжує демонструвати відсутність бачення ефективного реагування на грубі порушення Росією ключових принципів і зобов'язань у рамках Організації, зокрема тих, що містяться в Гельсінському Заключному акті. Керівний принцип консенсусу при ухваленні рішень в ОБСЕ дозволяє Росії блокувати ініціативи, спрямовані на відновлення поваги до принципів та зобов’язань у рамках Організації, що часом набуває з боку РФ ознак відвертого шантажу. При цьому варто зазначити, що Сербське головування ОБСЕ (2015 р.) та певною мірою Італійське (2018 р.) і Словацьке (2019 р.) упродовж терміну їх головувань демонстрували певну прихильність до позиції РФ, яка іноді йшла врозріз із роллю Головування як неупередженого політичного лідера Організації та головного гаранта дотримання норм, принципів та виконання зобов'язань державами-учасницями. Це проявлялося, зокрема, під час переговорного процесу щодо проєктів підсумкових документів на відповідних засіданнях РМЗС ОБСЕ.

Підсумки шістьох послідовних щорічних засідань РМЗС ОБСЕ (Базель-2014, Белград-2015, Гамбург-2016, Відень-2017, Мілан-2018, Братислава-2019) та безрезультатне завершення трирічного процесу «Гельсінкі+40» у 2015 р. засвідчили відсутність консенсусу, подальше поглиблення кризи та поляризацію позицій серед держав - учасниць ОБСЕ, що суттєво звузило можливості для пошуку компромісу з ключових питань порядку денного Організації. Російська сторона продовжувала здійснювати тиск на інші держави, у т. ч. й західних партнерів України, та активно підштовхувати до винесення «кримського питання» та відновлення поваги до порушених принципів і зобов'язань ОБСЕ за межі широкого безпекового діалогу, домагаючись формування т. зв. «позитивного» чи «об'єднуючого» порядку денного на основі спільного пошуку шляхів ефективної проти- дії зростаючим транснаціональним загрозам та позиціонування себе у якості світового лідера в боротьбі з міжнародним тероризмом. Цьому, зокрема, сприяло те, що в 2014-2016 рр. посаду керівника департаменту транснаціональних загроз Секретаріату ОБСЕ обіймав представник РФ, який, за інформацією розслідувань німецьких і австрійських ЗМІ, був генералом ФСБ РФ [13]. У цих же публікаціях йдеться і про інших високих представників спецслужб Росії, які під дипломатичним прикриттям працювали в Секретаріаті ОБСЕ.

У цьому контексті варто також нагадати, що з червня 2017 р. представник Росії В. І. Воронков обіймає посаду Заступника Генерального секретаря ООН, Директора Департаменту боротьби з тероризмом, що робить його головною посадовою особою на планеті Земля, відповідальною за глобальну боротьбу з тероризмом. I це при тому, що Росія цілою низкою міжнародно-правових документів та законодавчих актів України визнається країною - спонсором тероризму [14].

Таким чином, проблема російського впливу при формуванні консенсусу з ключових питань порядку денного ОБСЕ на основі найменшого спільного знаменника залишається актуальною, що потребує значних зусиль з боку України та іiі партнерів для консолідації ефективної дипломатичної протидії.

Головні завдання України в рамках Організації сім останніх років полягали у забезпеченні привернення належної уваги партнерів до фактів порушення РФ основоположних принципів та зобов'язань ОБСЄ, починаючи з незаконної окупації та спроб анексії Криму, нейтралізації будь-яких спроб інтерпретації ситуації на Донбасі як внутрішнього, громадянського конфлікту, підтримки діяльності СММ та автономних інститутів ОБСЕ як важливих чинників протидії міжнародного співтовариства російській військово-політичній агресії та політичній пропаганді. У цій роботі активно використовувалася як інформація регулярних звітів СММ, так і низки українських джерел, зокрема свідчення й докази Міністерства оборони та Служби безпеки України, матеріали незалежних журналістських та фахових міжнародних розвідувальних досліджень [11; 15-16]. Для доведення об'єктивної інформації до держав-учасниць, окрім заходів Постійної ради, активно використовувався також механізми військово-політичного виміру та майданчик Форуму безпекової 
співпраці ОБСЕ. Успішне чотиримісячне Головування України у Форумі (квітень-серпень 2020 р.) зробило суттєвий позитивний внесок $\mathbf{y}$ зазначену справу [17].

Ураховуючи консенсусний характер діяльності ОБСЄ та рівність їі держав-учасниць, доводиться констатувати, що практично незалежно від того, яка країна головує в ОБСЕ, всі вони так чи інакше розглядали Організацію як майданчик для налагодження «конструктивного» діалогу 3 Росією, вважаючи контрпродуктивним «конфронтаційний характер дискусій» (у т. ч. засудження порушень з боку РФ Мінських домовленостей, норм і принципів міжнародного права та ОБСЕ). 3 огляду на необхідність формування консенсусу навколо низки важливих рішень окремі Головування ОБСЕ часом вдавалися до посилення тиску на Україну з метою корегування iï позиції задля досягнення «компромісних» рішень. При цьому тверда принципова позиція України у відстоюванні національних інтересів та територіальної цілісності держави, активний iii супротив зазначеному безпідставному тиску, уникнення Росією будь-яких конструктивних компромісів призводили до неможливості ухвалення важливих для європейської безпеки, але суттєво вихолощених Росією рішень.

3 метою протидії російській агресії Україна забезпечує максимально повне та ефективне використання у своїх інтересах наявного інструментарію ОБСЕ. СММ відіграє сьогодні важливу роль у забезпеченні об'єктивного моніторингу ситуації на сході України та представлення його результатів світовій спільноті й широкій громадськості. Завдяки цілеспрямованим зусиллям партнерів України мобілізовані значні міжнародні фінансові ресурси для посилення діяльності СММ, зокрема їі ефективності. При цьому активно використовується експертний потенціал автономних інститутів ОБСЕ: БДІПЛ, ВКНМ, ПЗМІ. У центрі уваги перебувають численні порушення прав людини та основоположних свобод, спричинені незаконною окупацією Криму та збройною агресією Росії на Донбасі. Інститутами ОБСЕ готуються незалежні експертні висновки, які відповідають інтересам України та активно використовуються в контексті протидії російській агресії, захисту її суверенітету і територіальної цілісності, також і під час розгляду ініційованих нею судових справ проти Російської Федерації.
Численні заходи в рамках військово-політичного виміру ОБСЕ, участь у яких брали високі представники із столиць, дозволили Україні на високому рівні довести важливі сигнали та надати державам - учасницям ОБСЕ грунтовні роз'яснення про зовнішню природу триваючого конфлікту на сході України, спричиненого військовою агресією РФ, включно і факти безпосередньої участі ЗС РФ у бойових діях і надання військової та ресурсної підтримки незаконним збройним формуванням на Донбасі.

Хід засідань робочих органів ОБСЕ, а також підсумки регулярних консультацій, що проводяться з основними партнерами України (США, $\in C$, Канада, Велика Британія, Литва, Туреччина, Швейцарія та ін.) дають можливість скоординувати підходи з актуальних питань взаємодії в рамках урегулювання російсько-українського конфлікту. За їх підсумками можна констатувати схожість політичних оцінок процесу мирного врегулювання, визнання необхідності здійснення подальшого тиску на РФ, зокрема для досягнення згоди на можливе розгортання міжнародної миротворчої операції ООН на Донбасі, посилення СММ як єдиної наразі масштабної міжнародної присутності для стабілізації ситуації на Донбасі. Регулярно підтверджуються сигнали політичної підтримки України й готовність партнерів до розширення практичної допомоги та військової співпраці з нею.

Серед головних результатів функціонування СММ слід відзначити регулярні фіксації новітніх зразків російського озброєння, зокрема систем РЕБ, та відеоматеріали випадків незаконного перетину російсько-українського кордону військовими конвоями, що перевозять боєприпаси та військове обладнання. Проте російська сторона жодного разу не спромоглася дати будьякі пояснення цих дій, оскільки продовжує, всупереч численним фактам, категорично заперечувати свою причетність до окупації територій України та пряму участь у конфлікті. Важливим інструментом, який суттєво посилив можливості СММ, стало залучення БПЛА дальнього та середнього радіусу дії, які дають змогу здійснювати моніторинг у віддалених від лінії контакту прикордонних районах окупованих Росією територій Донбасу. Під тиском української сторони СММ почала більше уваги приділяти питанням, пов'язаним з окупованим Кримом. Так, до звіту СММ 2018 р. було включено інформацію про погіршення стану довкілля у Херсонській області через екологічну катастрофу на півночі 
Криму та про наслідки російської окупації для свободи судноплавства в Азовському морі. Водночас Місія продовжує відмовлятися фіксувати у звітах накладену на неї Росією заборону доступу до Криму та утримується від започаткування постійного дистанційного моніторингу.

Іншим ключовим напрямом використання Україною можливостей ОБСЕ для протидії російській агресії є проведення активної регулярної інформаційно-роз'яснювальної роботи серед делегацій держав - учасниць і партнерів ОБСЕ, а також інститутів і структур Організації, з метою збереження їх пріоритетної уваги до фактів російської агресії та ії̈ наслідків для європейської безпеки. На щоденній основі проводяться консультації, робочі зустрічі та діалоги з Головуванням ОБСЕ і провідними західними партнерами України. Підтримується постійна увага ОБСЕ до питання незаконно утримуваних російською стороною громадян України і політичних в'язнів Кремля, наголошується на необхідності їх негайного та безумовного звільнення. Висвітлювалися триваючі порушення Росією норм міжнародного права, зокрема невиконання припису МС ООН від 19 квітня 2017 р. щодо тимчасових заходів у справі «Україна проти РФ», протиправне будівництво мосту через Керченську протоку без згоди Уряду України та перепони, що чиняться судноплавству в Азовському морі та Керченській протоці.

Україна використовує засідання Організації для інформування держав-учасниць про грубі порушення Росією взятих зобов'язань у рамках ОБСЕ, наведення фактів постачання російських найманців, зброї і техніки через неконтрольовану ділянку українсько-російського кордону та свідому підтримку РФ терористичної діяльності на території нашої держави. Демонструвалися фото- і відеоматеріали з доказами російської військової присутності та повного контролю російської влади над гібридними збройними формуваннями на Донбасі, а також мілітаризації Криму, Чорного та Азовського морів. Інформувалося про протизаконну політику примусової паспортизації українських громадян і примусової конскрипції чоловічого українського населення для служби в російській армії на окупованих Росією територіях, проведення політики «етнічного інжинірингу» - витіснення десятків тисяч представників українського та кримськотатарського етнічного населення з Криму та завезення на півострів близько 1 млн російських громадян з різних регіонів РФ, що є злочинами відповідно до положень міжнародного гуманітарного права та Женевських конвенцій 1949 р. Особлива увага також приділялася висвітленню відповідальності РФ за збиття малайзійського пасажирського лайнера рейсу МН 17.

\section{Висновки та пропозиції}

Україні у їі протистоянні російській агресії для оптимізації та узгодження дій із відновлення територіальної цілісності в актуальних геополітичних умовах необхідно зосередитися на комплексному триєдиному завданні спільної реалізації трьох згаданих вище складових частин («стовпів») іiї пріоритетних політико-безпекових зусиль: повноформатна реалізація гарантій, наданих Україні ядерними державами відповідно до Будапештського меморандуму; розгортання на сході України повномасштабної комплексної (трикомпонентної) Міжнародної операції ООН з підтримання миру; продовження активного та повномасштабного залучення механізмів ОБСЕ.

Важливо забезпечувати збереження особливої уваги міжнародної спільноти до питань російської агресії проти України (військова інтервенція на Донбасі, мілітаризація Кримського півострова та розширення окупації на водні простори Чорного та Азовського морів, Керченської протоки. 3 огляду на консенсусний характер ухвалення ключових рішень в ОБСЄ головним інструментом має бути політико-дипломатичний тиск на країну-агресора, який не дозволяе їй домогтися виходу з міжнародної ізоляції та пом'якшення антиросійських санкцій.

Провідну роль відіграє СММ ОБСЕ, яка є цінним джерелом надійної та об’єктивної інформації, інструментом фіксацій порушень Росією взятих зобов'язань, навіть в умовах жорстких обмежень на діяльність Місії, накладених російською окупаційною адміністрацією, зокрема 3 весни 2020 p. під приводом коронавірусних обмежень.

ОБСЄ продовжує виконувати функцію посередника в рамках ТКГ, яка, незважаючи на невисоку ефективність, залишається важливим інструментом вирішення практичних питань, пов’язаних із російською агресією. 
Перспективним напрямом подальшого залучення потенціалу ОБСЄ до російсько-українського врегулювання має стати налагодження співпраці з Міжнародною операцією $\mathrm{OOH} з$ підтримання миру на Донбасі у разі ухвален-

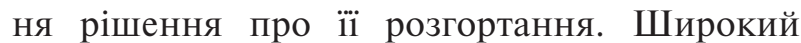
міжнародний досвід урегулювання подібних конфліктів, зокрема на Балканах, свідчить про його високу ефективність за формування широкої трикомпонентної операції. Активної протидії потребують спроби РФ звести проблематику російсько-українського конфлікту виключно до Донбасу і виконання Мінських домовленостей без уваги до проблеми деокупації Криму. Для всеохопного розв'язання конфлікту уявляється недоцільним розділення цих двох його невід'ємних складових ча- стин. Необхідно продовжити використання інструментарію ОБСЕ для протидії спробам російської окупаційної влади легітимізувати свою юрисдикцію в АРК та м. Севастополі, приховати факти військової гібридної агресії на Донбасі та уникнути міжнародно-правової відповідальності.

Потрібно максимально використовувати інструментарій ОБСЕ для політико-дипломатичного забезпечення ефективного захисту суверенітету та територіальної цілісності нашої держави, недопущення підміни цієї проблематики спробами налагоджувати діалог з Росією, за принципом «business as usual», із залишенням поза увагою дій РФ, спрямованих на підрив європейської безпеки.

\section{Список літератури}

1. Лоссовський I. До 20-ї річниці будапештських «гарантій»: Агресія Росії проти України як фактор ерозії міжнародно-правових режимів нерозповсюдження. Зовнішні справи. 2014. № 11. С. 6-11.

2. Лоссовський I. Міжнародно-правовий статус Будапештського меморандуму: Договір, обов'язковий для виконання всіма його сторонами. Київ : Українська асоціація зовнішньої політики, 2015. 128 с.

3. Lossovskyi, I. Russia's aggression against Ukraine as a destabilizing factor for non-proliferation regimes. UA: Ukraine Analytica. 2018. № 2 (12). Pp. 27-37.

4. Лоссовський І. Миротворча операція ООН в «сепаратистському» регіоні Хорватії (1995-1998 рр.): історичні аналогії, принципові відмінності та успішний досвід для Донбасу / Публікації Центру дослідження Росії. 2015. 04 серп. URL: http://www.r-studies.org/ (дата звернення: 20.09.2020).

5. Лоссовський I. Є. Можливості ООН і план «Б» врегулювання військово-політичної кризи на Донбасі // Сильна ООН - кращий світ : Міжнар. наук.-практ. конф., присвячена 70-й річниці заснування ООН. Київ : Дипломатична академія України, 2015. С. 77-80.

6. Лоссовський І. Миротворчий досвід ООН і план «Б» врегулювання військово-політичного конфлікту на сході України. Зовнішні справи. 2016. № 1. С. 11-15.

7. Лоссовський І. Миротворчий досвід ООН і план «Б» врегулювання військово-політичного конфлікту на сході України. Зовнішні справи. 2016. № 2. С. 16-20.

8. Заключительный акт Совещания по безопасности и сотрудничеству в Европе. URL: https://zakon.rada.gov. ua/laws/show/994_055\#Text (дата звернення: 20.09.2020).

9. Lossovskyi, I. The Activity of the OSCE from a Ukrainian Perspective // OSCE Yearbook 2003. Baden-Baden. Germany. Pp. 107-120.

10. Lossovskyi, I. Ukraine's Decade of Participation in the OSCE: Some Results and the Basic Priorities. Ukrainian Quarterly. 2003. № 1-2, Spring-Summer. N.Y., USA. Pp. 5-21.

11. Координатор проєктів ОБСЄ в Україні : офіц. сайт URL: https://www.osce.org/uk/project-coordinator-inukraine (дата звернення: 20.09.2020).

12. Спеціальна моніторингова місія ОБСЄ в Україні : офіц. сайт. URL: https://www.osce.org/ru/special-monitoringmission-to-ukraine (дата звернення: 20.09.2020).

13. Pawielski, Donald. Putin diskreditiert die Rolle Deutschlands in der OSZE / Wiener Zeitung Online. 2016.19 Juli. URL: https://www.meine-news.de/wiesen/c-politik/putin-diskreditiert-die-rolle-deutschlands-in-der-osze_a14914 (дата звернення: 20.09.2020).

14. Лоссовський I. Росія - держава ізгой. День. 2015. 07 квіт. URL: https://m.day.kyiv.ua/ru/article/mirovye-diskussii/ rosiya-derzhava-izgoy (дата звернення: 20.09.2020).

15. InformNapalm. International Intelligence Community. URL: https://informnapalm.org/en/ (дата звернення: 20.09.2020). 
16. Головне управління розвідки Міністерства оборони України : офіц. сайт. URL: https://gur.gov.ua/content/listof-news.html (дата звернення: 20.09.2020).

17. Підсумки Головування України в Форумі безпекової співпраці ОБСЄ. URL: https://www. ukrinform.ua/rubric-polytics/3068270-nimeccina-golovuvatime-u-forumi-obse-z-ukrainskou-bulavou. html?fbclid=IwAR2s1clhhcHrFxt-n4hoXoJuMIAmltHyENVuvSACbhchj8keNV8YbXjvk00 (дата звернення: 20.09.2020).

\section{References}

1. Lossovskyi, I. (2014). Do 20-yi richnytsi budapeshtskyh «harantii»: Ahresiia Risii proty Ukrainy yak factor erozii mizhnarodno-pravovykh rezhymiv nerozpovsiudzhennia [To the 20th anniversary of the Budapest «guarantees»: Russia's aggression against Ukraine as a factor in the erosion of international legal regimes of non-proliferation]. Zovnishni spravy - UA Foreign Affairs, 11, 6-11 [in Ukrainian].

2. Lossovsky, I. (2015). Mizhnarodno-pravovyi status Budapeshtskoho memoradumu: Dohovir, oboviazkovyi dlia vykonannia vsima yogo storonamy [International legal status of the Budapest Memorandum: A treaty binding on all parties]. Kyiv: Ukrainian Association of Foreign Policy (128 p.) [in Ukrainian].

3. Lossovskyi, I. (2018). Russia's aggression against Ukraine as a destabilizing factor for non-proliferation regimes. $U A$ : Ukraine Analytica, 2 (12), 27-37 [in Ukrainian].

4. Lossovskyi, I. (2015). Myrotvorcha operatsia OON v «separatystskomu» rehioni Khorvatii (1995-1998): istorychni analohii, pryntsypovi vidminnosti ta uspishnyi dosvid dlia Donbasu [UN peacekeeping operation in the "separatist» region of Croatia (1995-1998): historical analogies, fundamental differences and successful experience for Donbas]. Publications of the Center for Russian Studies. Aug. 4. r-studies.org. Retrieved from http://www.r-studies.org/ (viewed 20.09.2020) [in Ukrainian].

5. Lossovskyi, I. Ye. (2015). Mozhlyvosti OON i plan «B» vrehyliuvannia viiskovo-politychnoii kryzy na Donbasi [UN Opportunities and plan «B» for Resolving the Military-Political Crisis in Donbas]. In: International Scientific and Practical Conference Dedicated to the 70th Anniversary of the UN Foundation: «A Strong UN is a Better World». Kyiv: Diplomatic Academy of Ukraine (pp. 77-80) [in Ukrainian].

6. Lossovskyi, I. (2016). Myrotvorchyi dosvid OON i plan «B» vrehuliuvannia viiskovo-politychnogo konfliktu na skhodi Ukrainy [UN peacekeeping experience and plan «B» settlement of the military-political conflict in eastern Ukraine]. Zovnishni spravy - UA Foreign Affairs, 1, 11-15 [in Ukrainian].

7. Lossovskyi, I. (2016). Myrotvorchyi dosvid OON i plan «B» vrehuliuvannia viiskovo-politychnogo konfliktu na skhodi Ukrainy [UN peacekeeping experience and plan «B» settlement of the military-political conflict in eastern Ukraine]. Zovnishni spravy - UA Foreign Affairs, 2, 16-20 [in Ukrainian].

8. Zakliuchitelnyi akt Soveshchania po bezopasnosti i sotrudnichestvu v Yevrope [Final Act of the Conference on Security and Cooperation in Europe]. (n. d.). zakon.rada.gov.ua. Retrieved from https://zakon.rada.gov.ua/laws/ show/994_055\#Text (viewed 20.09.2020) [in Russian].

9. Lossovskyi, I. (2003). The Activity of the OSCE from a Ukrainian Perspective. OSCE Yearbook 2003. Baden-Baden. Germany (pp. 107-120) [in English].

10. Lossovskyi, I. (2003). Ukraine's Decade of Participation in the OSCE: Some Results and the Basic Priorities. Ukrainian Quarterly, 1-2, Spring-Summer. N.Y., USA (pp. 5-21) [in English].

11. Koordinator proektiv OBSE v Ukraini [OSCE Project Coordinator in Ukraine]. (n. d.). osce.org. Retrieved from https://www.osce.org/uk/project-coordinator-in-ukraine (viewed 20.09.2020) [in Ukrainian].

12. Spetsialna monotorynhova misia OBSE v Ukraini [OSCE Special Monitoring Mission to Ukraine]. (n. d.). osce. org. Retrieved from https://www.osce.org/ru/special-monitoring-mission-to-ukraine (viewed 20.09.2020) [in Ukrainian].

13. Pawielski, Donald. (2016). Putin discredited the role of Germany in the OSCE. Wiener Zeitung Online. 19 Juli. meinenews.de. Retrieved from https://www.meine-news.de/wiesen/c-politik/putin-diskreditiert-die-rolle-deutschlandsin-der-osze_a14914 (viewed 20.09.2020) [in German].

14. Lossovskyi, I. (2015). Rosiia - derzhava izhoi [Russia a rogue state]. m.day.kyiv.ua. Retrieved from https://m.day. kyiv.ua/ru/article/mirovye-diskussii/rosiya-derzhava-izgoy (viewed 20.09.2020) [in Ukrainian].

15. InformNapalm. International Intelligence Community. (n. d.). informnapalm.org. Retrieved from https:// informnapalm.org/en/ (viewed 20.09.2020) [in Ukrainian].

16. Holovne upravlinnia rozvidky Ministerstva oborony Ukrainy [Main Intelligence Directorate of the Ministry of Defense of Ukraine]. (n. d.). gur.gov.ua. Retrieved from https://gur.gov.ua/content/list-of-news.html (viewed 20.09.2020) [in Ukrainian].

17. Pidsumky Holovuvannia Ukrainy v Forumi bezpekovoi spivpratsi OBSE [Results of the Chairmanship of Ukraine in the OSCE Forum for Security Co-operation]. (n. d.). ukrinform.ua. Retrieved from https://www.ukrinform.ua/rubricpolytics/3068270-nimeccina-golovuvatime-u-forumi-obse-z-ukrainskou-bulavou.html?fbclid=IwAR2s $1 \mathrm{clhh}$ (viewed 20.09.2020) [in Ukrainian]. 